\title{
PERAN HUMAN CAPITAL BAGI KEUNGGULAN KOMPETITIF ORGANISASI: SEBUAH TINJAUAN
}

\author{
Suryono Efendi \\ Universitas Nasional Jakarta \\ Email: suryono.efendi@yahoo.com
}

\begin{abstract}
Abstrak
Penurunan saat ini di berbagai perekonomian dunia telah mengakibatkan human capital semakin penting dengan meningkatnya globalisasi dan kejenuhan pasar kerja. Untuk meningkatkan pertumbuhan ekonomi dengan memberikan lebih banyak waktu dan upaya, baik negara maju maupun negara berkembang menekankan pada pengembangan SDM. Pengembangan SDM adalah salah satu jawaban mendasar untuk arena dunia. Untuk mencapai hal ini, perusahaan harus menemukan resource yang diperlukan untuk mengembangkan SDM dengan pengaruh yang lebih besar terhadap kinerja. Studi ini mengkaji dampak human capital dari beberapa sudut pandang kritis terhadap kinerja perusahaan. Keberhasilan perusahaan dinilai dari segi finansial dan non finansial. Studi ini, akhirnya, menyajikan model dasar yang menjelaskan hubungan antara human capital dan pencapaian bisnis.
\end{abstract}

Kata Kunci: Human Capital, Kinerja, Perusahaan.

\section{Abstract}

With rising globalization and labor market saturation, the present downturn in many international economies has emphasized the importance of human capital. Both developed and developing countries place a premium on human resource development in order to boost economic growth through increased time and effort. Human resource development is a critical component in entering the international arena. To do this, businesses must invest the required resources in developing human capital that has a stronger influence on performance. From a variety of critical viewpoints, the influence of this paper evaluation on human capital has a direct effect on company performance. The success of the business is measured in both financial and non-financial parameters. Finally, this article develops an early model of the connection between human capital and business performance.

Keywords: Human Capital, Performance, Company.

\section{A. PENDAHULUAN}

Bisnis adalah kumpulan sumber daya yang dapat diklasifikasikan dalam beberapa kategori, seperti keuangan, fisik, sumber daya manusia, pengetahuan dan pembelajaran, serta sumber daya bisnis umum (Ekawati \& Soleha, 2017). Perusahaan yang sukses adalah perusahaan yang berhasil memasok, mengembangkan, dan mengelola sumber daya dan keterampilannya sebagai keunggulan kompetitif dalam jangka panjang (Hanggraeni, 2012). Sebuah organisasi berkinerja tinggi membutuhkan tenaga kerja berkinerja tinggi.

"Ilmu ekonomi" muncul di Olssen \& Peters (2005), di mana orang adalah komponen produksi kunci dan satu-satunya aspek keberhasilan perusahaan yang tidak dapat ditransfer sebagai komoditas. Di Inggris, sebuah integrasi dalam siklus manajemen dibangun antara 
manajemen Sumber Daya Manusia yang baik dan kinerja organisasi. Sampai saat ini, keberhasilan perusahaan hanya dinilai dari keberhasilan finansial, namun hal ini tidak realistis dalam hal daya saing yang sebenarnya dan tidak dapat meramalkan kinerja perusahaan di masa depan (Nurjanah, 2014).

Sumber daya manusia sangat penting untuk menjalankan bisnis. Namun, tidak semua bisnis menghargai fungsi kritis sumber daya manusia, yang membuatnya terlalu mudah untuk membuang 'orang' di dalamnya. Memang banyak yang arogan dan mengatakan merekrut pegawai baru itu mudah karena banyak yang mengantre untuk mendapatkan pekerjaan, sehingga mengabaikan hak-hak pegawai yang ada (Rahman, 2009). Perusahaan memahami peran vital pekerja dalam keberhasilan bisnisnya di masa kemajuan pesat dan canggih dalam ilmu pengetahuan dan teknologi. Karyawan tidak lagi dianggap sebagai sumber daya dasar, tetapi aset vital bagi keberadaan dan perkembangan perusahaan. Ini adalah periode sumber daya manusia ditransformasikan menjadi human capital (Hidayat, 2013).

Metode dimana orang memperoleh keterampilan adalah pengembangan sumber daya manusia. Proses ini membantu organisasi untuk memperoleh atau meningkatkan keterampilan yang diperlukan untuk melakukan fungsi yang berbeda terkait dengan peran mereka yang ada atau yang diantisipasi di masa depan secara berkelanjutan dan terencana. Ini membantu organisasi untuk mengembangkan keterampilan mereka, menemukan dan memanfaatkan potensi internal mereka untuk pengembangan mereka sendiri dan/atau organisasi (Widodo, 2010).

Saat menganalisis masalah tentang apa yang berkontribusi pada keunggulan kompetitif, lebih banyak penekanan telah diletakkan pada sumber daya internal yang dipandang penting untuk mempertahankan efektivitas daripada pada posisi eksternal dalam industri dan keseimbangan relatif dari kekuatan kompetitif bekerja menunjukkan awal dari pandangan berbasis sumber daya perusahaan yang kemudian dipoles. Resource Based Vief telah membuktikan pentingnya bisnis dalam membangun rangkaian sumber daya yang berharga dan menghubungkannya dengan kesuksesan dalam berbagai cara yang berbeda (RBV). Tidak seperti kepercayaan sebelumnya, keunggulan persaingan tidak dapat ditiru oleh sumber daya alam, teknologi, dan skala ekonomi. Keunggulan kompetitif terletak pada sumber daya yang berharga, tidak biasa, sulit untuk disalin dalam bisnis, menurut RBV. Dalam arti akhirnya, human capital adalah aset yang tidak terlihat." Untuk tujuan strategis bisnis, dengan demikian menjadi jelas betapa pentingnya kumpulan human capital (kumpulan keterampilan karyawan) dan bagaimana hal itu dikelola melalui prosedur SDM.

\section{B. METODE}

Metode deskriptif kualitatif berdasarkan tinjauan pustaka digunakan dalam penelitian ini. Ketika memilih metode ini, penjelasan rinci tentang persyaratan khusus pada item tertentu harus diberikan (Sugiyono, 2011). Penulis berusaha dalam contoh ini untuk mendapatkan gambaran tentang ide human capital dan dampaknya terhadap keunggulan kompetitif organisasi. Pengumpulan data dalam penelitian ini dilakukan dengan dua cara yaitu data primer dan data sekunder. Informasi utama untuk penelitian ini adalah dalam bukubuku, publikasi ilmiah, jurnal dan artikel. Sumber daya internet tambahan dapat digunakan untuk menawarkan data sekunder. 


\section{HASIL DAN PEMBAHASAN}

Ungkapan human capital didirikan untuk meningkatkan produktivitas dan mempertahankan keunggulan kompetitif sebagai faktor penting untuk memperluas bisnis dan aset karyawan. Sumber daya manusia merupakan instrumen peningkatan produktivitas untuk menjaga daya saing dalam organisasi (Putri \& Kurnia, 2016). Human capital pada dasarnya adalah sarana pendidikan, pelatihan, dan upaya profesional lainnya yang melekat untuk meningkatkan tingkat pengetahuan, keterampilan, bakat, dan aset sosial karyawan. Ini mengarah pada kebahagiaan dan kinerja bagi karyawan dan mengarah pada kinerja perusahaan. Oleh karena itu, konsep human capital disebut sebagai 'pengetahuan, keterampilan, bakat, dan kualitas yang tercakup dalam manusia yang mendorong pengembangan kesejahteraan pribadi, sosial, dan ekonomi.' Lingkungan bisnis yang terus berubah membutuhkan bisnis untuk mencari keunggulan kompetitif yang lebih baik melalui rencana bisnis dinamis yang memadukan kreativitas dengan inovasi. Untuk kelangsungan hidup jangka panjang, ini penting. Kontribusi sumber daya manusia untuk meningkatkan daya saing perusahaan sangat jelas (Sunarsih, 2018).

Telah ada penelitian yang signifikan tentang human capital dan pengaruhnya terhadap kinerja bisnis untuk meningkatkan daya saing dan kinerja sumber daya manusia. Ada hubungan yang signifikan antara inovasi dan kinerja perusahaan dalam gagasan human capital. Konsep kinerja bisnis dapat berkisar. Namun, definisi tertentu yang jelas tentang kinerja perusahaan sehubungan dengan peningkatan modal dapat diberikan. Selain itu, laba atas investasi, laba per saham dan laba bersih setelah pajak juga dapat digunakan sebagai ukuran kinerja keuangan (Melia, 2015). Menariknya, peneliti juga cenderung membandingkan indikator akuntansi manajerial terhadap ukuran keuangan dalam enam dimensi; kompensasi pekerja ${ }^{e e}$ (biaya kompensasi pekerja dibagi dengan penjualan); kualitas ${ }^{\text {ee }}$ (jumlah kesalahan dalam produksi); penyusutan"e (misalnya kehilangan persediaan, cacat, retur penjualan); produktivitase (biaya penggajian dibagi dengan output); biaya operasie (biaya operasi total dibagi dengan penjualan). Pendekatan kinerja yang dirasakan (disebut sebagai ukuran kinerja subjektif) dapat digunakan untuk mengukur kinerja perusahaan. Kinerja perusahaan dari manajemen puncak dapat diukur dengan menggunakan penskalaan seperti Likert (Sawitri, 2011).

Hubungan Human Capital dengan Kinerja Perusahaan, Human capital memfokuskan pada dua komponen utama yaitu individu dan organisasi. Lebih lanjut menjelaskan bahwa human capital memiliki empat atribut dasar: (1) fleksibilitas dan kemampuan beradaptasi (2) peningkatan kompetensi individu (3) pengembangan kompetensi organisasi dan (4) kemampuan kerja individu. Ini menunjukkan bahwa atribut ini pada gilirannya menghasilkan nilai tambah bagi hasil individu dan organisasi. Ada berbagai temuan yang menggabungkan human capital dengan kinerja yang lebih tinggi dan keunggulan kompetitif yang berkelanjutan; komitmen organisasi yang lebih tinggi; dan peningkatan retensi organisasi; Semua diskusi ini berfokus pada kinerja individu dan organisasi. menemukan bahwa signifikansi human capital tergantung pada sejauh mana kontribusinya terhadap pembentukan kinerja perusahaan (Sukoco \& Prameswari, 2017). Secara ekonomi, biaya transaksi menunjukkan bahwa perusahaan memperoleh keunggulan kompetitif ketika mereka memiliki sumber daya spesifik perusahaan yang tidak dapat ditiru. Dengan demikian, ketika keunikan human capital meningkat, perusahaan memiliki insentif untuk menginvestasikan sumber daya 
ke dalam manajemennya dan bertujuan untuk mengurangi risiko dan memanfaatkan potensi produktif (Sukoco \& Prameswari, 2017).

Oleh karena itu, individu perlu meningkatkan keterampilan kompetensi mereka agar dapat bersaing dalam organisasi mereka. Teori human capital telah mengalami perkembangan yang pesat. Dalam perkembangannya, perhatian yang lebih besar telah diberikan pada aspekaspek terkait pelatihan. Ini sangat terkait dengan perspektif individu. Setiap tindakan yang meningkatkan kualitas (produktivitas) karyawan adalah investasi dalam human capital. Oleh karena itu, pelatihan merupakan bagian penting dari investasi dalam human capital (Prasetyo, 2008). Hal ini mengacu pada pengetahuan dan pelatihan yang dibutuhkan dan dialami oleh seseorang yang meningkatkan kemampuannya dalam melakukan kegiatan yang bernilai ekonomi. Beberapa literatur terbaru menunjukkan pentingnya pelatihan. Bagaimanapun, tepat untuk menunjukkan bahwa kurangnya pelatihan tenaga kerja terkait dengan daya saing yang rendah. Pada gilirannya, stok human capital yang lebih besar dikaitkan dengan produktivitas yang lebih besar dan gaji yang lebih tinggi. Demikian juga, pelatihan terkait dengan umur panjang perusahaan dan kecenderungan yang lebih besar untuk pertumbuhan bisnis dan ekonomi. Widjanarko (2006) menemukan bahwa human capital memotivasi pekerja, meningkatkan komitmen mereka dan juga menciptakan pengeluaran dalam R \& $\mathrm{D}$ dan akhirnya menciptakan jalan bagi generasi baru bagi perekonomian dan masyarakat pada umumnya. Selain itu, itu adalah berharga untuk usaha kecil yang berhubungan positif dengan kinerja bisnis. Akhirnya, investasi dalam pelatihan diinginkan baik dari perspektif pribadi maupun sosial. Dari tingkat organisasi, human capital memainkan peran penting dalam perencanaan strategis tentang bagaimana menciptakan keunggulan kompetitif. Dua dimensi human capital perusahaan adalah nilai dan keunikan. Perusahaan menunjukkan bahwa sumber daya berharga ketika mereka memungkinkan meningkatkan efektivitas, memanfaatkan peluang dan menetralisir ancaman (Sugiono \& Efendi, 2019). Dalam konteks manajemen yang efektif, nilai menekankan pada peningkatan keuntungan daripada biaya yang terkait. Dengan cara ini, human capital perusahaan dapat meningkatkan nilai jika berkontribusi pada biaya yang lebih rendah, memberikan peningkatan kinerja.

Studi lain oleh Habibah \& Riharjo (2016) menganalisis hubungan antara human capital dan kinerja organisasi perusahaan manufaktur. Mereka menunjukkan bahwa pada kinerja organisasi, indikator human capital memiliki hubungan positif. Indikator seperti pelatihan yang diikuti dan praktik kerja tim menghasilkan kinerja yang luar biasa di mana lebih banyak produktivitas dapat diterjemahkan ke dalam kinerja organisasi. Penelitian yang dilakukan oleh Hartini (2012) juga mendukung hal ini, yang menunjukkan bahwa kualitas pengembang dan volume pangsa pasar berhubungan positif secara signifikan. Kami dapat menyimpulkan, berdasarkan pertimbangan sebelumnya, bahwa indikator sumber daya manusia secara langsung atau tidak langsung meningkatkan kinerja perusahaan. Menurut studi Ritonga (2019) menemukan hasil dari manajemen human capital. Mereka mengembangkan hubungan antara manajemen human capital dan hasil ekonomi dan bisnis. Hampir 25 perusahaan di bidang jasa keuangan telah dipilih dalam penelitian ini. Empat metrik yang digunakan untuk mengukur efektivitas sumber daya manusia: faktor pendapatan, faktor biaya, faktor pendapatan dan HC ROI. Aspek mendasar dari setiap organisasi adalah untuk menghasilkan lebih banyak pendapatan dan pendapatan per karyawan. Human capital secara langsung mempengaruhi aset modal intelektual yang memberikan hasil keuangan yang 
lebih tinggi per karyawan. Tingkat pendidikan karyawan dan kepuasan mereka secara keseluruhan berpengaruh positif terhadap perkembangan sumber daya manusia. Itulah sebabnya ROI perusahaan secara langsung dipengaruhi oleh perkembangan human capital. Mengembangkan model kasual menggunakan satu set data cross-sectional. Menunjukkan bahwa peningkatan human capital membuka jalan bagi inovasi yang lebih besar dan ini pada gilirannya menawarkan implikasi positif pada kinerja perusahaan (Sayyidah \& Saifi, 2017).

Sementara itu, human capital dan kinerja perusahaan dapat dilihat dalam konteks sistem kerja berkinerja tinggi. Hal yang banyak diperdebatkan adalah bahwa kinerja tinggi atau sistem kerja kinerja tinggi akan dihasilkan dari pembentukan dan penekanan pada peningkatan human capital. Tidak dapat dipungkiri bahwa peningkatan human capital dalam suatu organisasi memberikan kontribusi yang signifikan terhadap kompetensi organisasi. Hal ini kembali mendorong untuk lebih meningkatkan inovasi dan literatur saat ini yang mendukung fakta bahwa kinerja perusahaan dipengaruhi secara positif oleh human capital. Beberapa bahkan mendukung bahwa pengembangan human capital merupakan prasyarat untuk kinerja keuangan yang baik dan di samping itu, pentingnya human capital organisasi berkaitan dengan kinerja perusahaan lebih lanjut ( Putri, 2013). Selain itu, dijelaskan melalui bukti bahwa human capital relevan dengan kinerja perusahaan yang telah menjadi lazim di antara usaha baru berbasis teknologi. Tampaknya penggunaan human capital (menekankan kualitas karyawan) per katakanlah dalam usaha baru berbasis teknologi kecil tampaknya memiliki pengaruh besar pada keberhasilan perusahaan. Sementara peningkatan sumber daya manusia dapat dilihat dalam konteks heterogenitas manajemen puncak yang terkadang dapat disebut sebagai keragaman akan menghasilkan kinerja yang lebih besar. Pasalnya, perdebatan tersebut adalah heterogenitas yang mengembangkan berbagai karakteristik untuk diserap dalam tim tenaga kerja. Ini melibatkan orang-orang dari kelompok usia yang berbeda, latar belakang fungsional, latar belakang pendidikan, jenis kelamin dan masa kerja. Semua karakteristik ini memiliki pengaruh positif terhadap kinerja perusahaan. Studi menunjukkan bahwa heterogenitas menghasilkan pengetahuan, inovasi, dan kreativitas yang lebih besar di antara anggota tim. Heterogenitas secara positif melekat pada pemecahan masalah yang lebih baik dan menawarkan solusi kreatif. Oleh karena itu, keragaman berhubungan positif dengan kinerja. Bahkan dalam konteks organisasi, penerapan pendekatan atau filosofi manajemen tertentu juga berkaitan dengan pemasukan human capital ((misalnya lingkaran kualitas, tim ahli karyawan) terutama ketika menghadapi masalah. diskusi luas, terutama dalam konteks manajemen kualitas total, perusahaan dapat dinilai menggunakan kinerja keuangan dan non-keuangan (Jannah \& Marita, 2019).

Kinerja fungsional mencakup produktivitas karyawan, tingkat cacat dan pangsa pasar sedangkan kinerja non-fungsional melibatkan peningkatan alur kerja, inovasi, kepuasan pelanggan, dan pengembangan keterampilan. Seiring dengan keragaman ini, menarik dan mempertahankan talenta terbaik yang tersedia, biaya yang lebih rendah karena pergantian yang lebih rendah dan sedikit tuntutan hukum, pemahaman pasar dan kemampuan pemasaran yang ditingkatkan. Heterogenitas dianggap secara positif melekat pada pemecahan masalah yang lebih baik dan menawarkan solusi kreatif. Sebuah studi baru-baru ini di bidang terkait juga memberikan beberapa informasi mendalam tentang efek heterogenitas pada kinerja perusahaan. Tidak diragukan lagi, heterogenitas (dalam bentuk human capital) dapat menjadi masukan yang sangat penting untuk pengembangan dan peningkatan sumber daya manusia 
karena membuat organisasi untuk menjadi lebih kreatif dan inovatif untuk kelangsungan hidup jangka panjang di pasar internasional dan global mereka. Human capital internasional berbasis input, human capital transformasional dan human capital internasional berbasis output mendukung kompetensi TMT (Melani, 2016).

Teori human capital berakar dari bidang teori pembangunan ekonomi makro buku klasik, Human Capital: Domain ini diilustrasikan oleh analisis Teoritis dan Empiris dengan penekanan khusus pada pendidikan. Oleh karena itu, gagasan modal sepenuhnya konsisten dengan definisi tradisional bahwa pengeluaran untuk pendidikan, pelatihan, dan perawatan medis merupakan investasi dalam modal. Ini bukan hanya biaya, tetapi investasi dengan pengembalian kuantitatif yang berarti. Dari sudut pandang teori ekonomi komersial tradisional dalam hal jual beli, human capital dapat dianggap sebagai komoditas. Teori klasik menyoroti penggunaan modal kerja, dan pengetahuan dan keterampilan yang diperoleh seseorang melalui pendidikan dan pelatihan disebut sebagai human capital. Perbedaan antara human capital khusus perusahaan dan human capital generik Contoh human capital perusahaan adalah keterampilan yang diperoleh melalui pendidikan dan pelatihan di bidang akuntansi, sistem manajemen informasi dan kemampuan lain yang relevan dengan perusahaan tertentu. Sementara itu, tujuan keseluruhan human capital adalah pengetahuan yang diperoleh melalui pelatihan dan pelatihan nilai untuk berbagai organisasi, seperti keahlian yang luas dalam pengembangan sumber daya manusia. Pelatihan dan pendidikan adalah investasi human capital yang utama (Becker, 1994).

Hubungan antara sumber daya manusia dan kinerja semakin banyak diteliti. Meski kasusnya tidak kedap udara, bobot bukti mulai muncul karena beberapa alasan metrologi. Temuan penting dari penelitian ini adalah bahwa model kontingensi dan praktik terbaik dapat saling melengkapi untuk menciptakan kondisi bagi manajemen sumber daya manusia yang efektif. Artinya penerapan praktik kinerja tinggi seperti pembayaran berbasis insentif atau pemilihan staf, adalah bagian dari membangun arsitektur SDM. Kesamaan dapat ditemukan dalam pengukuran human capital. Mungkin menunjukkan sejumlah besar kemungkinan dan kelainan yang melekat pada perusahaan tertentu. Namun, hanya bergantung pada ukuran kinerja keuangan dapat menghasilkan evaluasi yang sangat parsial. Pandangan pemangku kepentingan atau pendekatan balanced scorecard dipandang paling tepat untuk menangkap kompleksitas kegiatan sumber daya manusia. Penekanan pada human capital dalam organisasi mencerminkan pandangan bahwa nilai pasar kurang bergantung pada sumber daya berwujud, melainkan pada yang tidak berwujud, khususnya sumber daya manusia. Merekrut dan mempertahankan karyawan terbaik, bagaimanapun, hanyalah bagian dari persamaan. Organisasi juga harus meningkatkan keterampilan dan kemampuan karyawannya dengan mendorong pembelajaran individu dan organisasi dan menciptakan lingkungan yang mendukung di mana pengetahuan dapat dibuat, dibagikan, dan diterapkan. Dalam tinjauan ini, kami akan menilai konteks di mana human capital sedang dibahas dan mengidentifikasi elemen kunci dari konsep tersebut, dan keterkaitannya dengan bentuk modal pelengkap lainnya, terutama intelektual, sosial, dan organisasi. Kami kemudian akan memeriksa kasus human capital yang berdampak pada kinerja, yang buktinya sekarang berkembang, dan mengeksplorasi mekanisme untuk mengukur human capital. 


\section{KESIMPULAN}

Makalah ini mempelajari literatur saat ini dan pengaruhnya terhadap kinerja perusahaan. Konseptualisasi human capital terkait dengan dasar-dasar kinerja ekonomi dan perusahaan. Menurut literatur ada bukti kuat untuk menunjukkan 'infus peningkatan human capital'. Dalam organisasi dan mengembangkan inovasi dan kinerja perusahaan yang lebih besar. Menurut penelitian, kinerja keuangan dipengaruhi secara positif melalui pertimbangan human capital. Berdasarkan hal ini, kinerja perusahaan dalam kaitannya dengan sumber daya manusia tidak boleh dianggap sebagai fenomena yang menambah angka nol dalam laba perusahaan. Pada dasarnya mengubah seluruh tenaga kerja sebagai aset paling berharga sehingga menciptakan jalan bagi organisasi untuk pencapaian yang lebih besar melalui kreativitas dan inovasi. Oleh karena itu, perusahaan harus membawa beberapa rencana yang efektif dan berguna untuk menginvestasikan berbagai aspek human capital. Ini tidak hanya mengarahkan perusahaan untuk mencapai kinerja yang lebih besar tetapi juga membuat perusahaan tetap kompetitif untuk kelangsungan hidup jangka panjang.

\section{DAFTAR PUSTAKA}

Becker, G. S. (1994). Human Capital Revisited. In Human Capital: A Theoretical And Empirical Analysis With Special Reference To Education, Third Edition (Pp. 15-28). The University Of Chicago Press.

Brummet, R. L., Flamholtz, E. G., \& Pyle, W. C. (1968). Human Resource measurement--A challenge for accountants. The Accounting Review, 43(2), 217-224.

Ekawati, R., \& Soleha, L. K. (2017). Meningkatkan Kemampuan Inovasi Organisasi Melalui Human Capital. Jurnal INTEKNA, 12(2), 79-147.

Habibah, B. N., \& Riharjo, I. B. (2016). Pengaruh Intellectual Capital Terhadap Kinerja Keuangan Pada Perusahaan Manufaktur. Jurnal Ilmu dan Riset Akuntansi (JIRA), 5(7).

Hanggraeni, D. (2012). Manajemen Sumber Daya Manusia. Jakarta: Universitas Indonesia Publishing.

Hartini, S. (2012). Peran Inovasi: Pengembangan Kualitas Produk dan Kinerja Bisnis. Jurnal Manajemen dan Kewirausahaan (Journal of Management and Entrepreneurship), 14(1), 83-90.

Hidayat, C. (2013). Analisis Model Pengukuran Human Capital Dalam Organisasi. Binus Business Review, 4(2), 879-885.

Jannah, M., \& Marita, K. W. (2019). Pengaruh Keragaman Dewan Direksi Terhadap Kinerja Keuangan (Doctoral Dissertation, IAIN Surakarta).

Melani, E. (2016). Pengaruh Tidak Langsung Human Capital Melalui Elemen Intellectual Capital Terhadap Kinerja Perusahaan. In Symposium Nasional Akuntannsi Lampung XIX.

Melia, A. (2015). Pengaruh Good Corporate Governance Terhadap Kinerja Perusahaan pada Sektor Keuangan. Business Accounting Review, 3(1), 223-232.

Nurjanah, S. (2014). Human Capital dan Peranan Pemerintah Dalam Pendidikan. Econosains Jurnal Online Ekonomi dan Pendidikan, 12(1), 83-90.

Olssen, M., \& Peters, M. A. (2005). Neoliberalism, higher education and the knowledge economy: From the free market to knowledge capitalism. Journal of education policy, 20(3), 313-345. 
Prasetyo, P. E. (2008). The Quality of Growth: Peran Teknologi dan Investasi Human Capital sebagai Pemacu Pertumbuhan Ekonomi Berkualitas. JEJAK: Jurnal Ekonomi dan Kebijakan, 1(1).

Putri, N. K. (2013). Peran Human Capital terhadap Kesuksesan Organisasi: Karyawan Adalah Investasi. Jurnal Administrasi Kebijakan Kesehatan, 11(2), 93-97.

Putri, Y. M., \& Kurnia, K. (2016). Pengaruh Modal Intelektual Terhadap Profitabilitas Dan Produktivitas Perusahaan Dalam Index LQ45. Jurnal Ilmu dan Riset Akuntansi (JIRA), 5(3).

Rahman, A. (2009). Manajemen Sumber Daya Manusia. Cetakan Pertama. Bandung: Citapustaka Media Perintis.

Ritonga, Z. (2019). Analisis Pengaruh Human Capital Terhadap Kinerja Karyawan Pada PT. Mustika Asahan Jaya. ECOBISMA (Jurnal Ekonomi, Bisnis dan Manajemen), 6(1), 23-28.

Sawitri, P. (2011). Interaksi Budaya Organisasi dengan Sistem Pengendalian Manajemen Terhadap Kinerja Unit Bisnis Industri Manufaktur dan Jasa. Jurnal Manajemen dan Kewirausahaan, 13(2).

Sayyidah, U., \& Saifi, M. (2017). Pengaruh Intellectual Capital Terhadap Nilai Perusahaan Dengan Profitabilitas Sebagai Variabel Moderasi (Studi Pada Perusahaan Sub Sektor Property dan Real Estate di Bursa Efek Indonesia Periode 2013-2015). Jurnal Administrasi Bisnis, 46(1), 163-171.

Sugiono, E., \& Efendi, S. (2019). Strategi Peningkatan Keunggulan Bersaing IKM: Peran Pembelajaran Organisasi dan Inovasi. Jurnal Riset Manajemen dan Bisnis (JRMB) Fakultas Ekonomi UNIAT, 4(1), 45-56.

Sugiyono, P. (2011). Metodologi Penelitian Kuantitatif Kualitatif Dan R\&D. Bandung: Alfabeta.

Sukoco, I., \& Prameswari, D. (2017). Human Capital Approach to Increasing Productivity of Human Resources Management. AdBispreneur: Jurnal Pemikiran dan Penelitian Administrasi Bisnis dan Kewirausahaan, 2(1).

Sunarsih, N. (2018). Manajemen Sumber Daya Manusia Berbasis Kompetensi: Strategi Meningkatkan Kemampuan Daya Saing Perusahaan. Jurnal Akrab Juara, 3(1), 17-28.

Widjanarko, I. (2006). Perbandingan Penerapan Intellectual Capital Report antara Denmark, Sweden dan Austria (Studi Kasus Systematic, Sentensia Q dan Oenb). Universitas Islam Indonesia.

Widodo, W. (2010). Model Pengembangan Human Capital Dalam Konteks Modal Sosial. Benefit: Jurnal Manajemen dan Bisnis, 13(2), 69-103. 